\title{
A Government Devoid of Strong Leadership: A Neoclassical Realist Explanation of Turkey's Iraq War Decision in 2003
}

\author{
Samet Yilmaz \\ Bursa Uludă̆ University
}

\begin{abstract}
This study deals with Turkey's Iraq War Decision that led up to the March 1 Parliamentary Motion Crisis in 2003 from the perspective of neoclassical realism, which analyzes the interaction between systemic and unit-level variables. The United States requested Turkey's collaboration in the war against Iraq. The Justice and Development Party (AK Party) government initially sought a peaceful settlement but eventually decided to align with the United States. Systemic and structural factors made cooperation with the United States an imperative for Turkey, which may be classified as a secondary state in the regional context. While the domestic political environment was favorable for the Turkish government to reach such a decision, it was hindered by the Grand National Assembly of Turkey (GNAT). In this framework, the study has two primary purposes. The first is to prove that in restrictive international environments where opportunities and threats are clear and the decision-making process is constrained by time, domestic divisions may matter in foreign policy and prevail over the systemic imperative, contrary to conventional expectations. The second is to demonstrate that in a restrictive international milieu, strong leadership, a factor underappreciated by neoclassical realists, is essential even for single-party governments, which are normally expected to have greater autonomy in democratic parliamentary systems, to formulate foreign policy.
\end{abstract}

Keywords: Neoclassical Realism, Turkey's Iraq War Decision, Justice and Development Party, March 1 Motion

\section{Introduction}

As soon as it came to power in November 2002, the AK Party faced a global challenge. ${ }^{1}$ The United States requested Turkey's collaboration in the war against Iraq and demanded the deployment of American troops in Turkish territory to open a northern front. The AK Party government decided to cooperate with the United States, but the parliamentary decision that would enable such cooperation failed to pass at the GNAT in what came to be known as the March 1 (2003) Motion. This development was interesting. Turkey has had close relations with the United States since the $1950 \mathrm{~s},{ }^{2}$ despite occasional frictions and bouts of increasing

\footnotetext{
Samet Y1lmaz, PhD, Research Assistant, Department of International Relations, Bursa Uludağ University. Email: sametyilmaz@ uludag.edu.tr. (D) 0000-0002-5232-5435.

This study is an updated version of the unpublished master's thesis completed in 2014.

1 Abdurrahman Babacan, “AK parti dönemi ilk küresel karşılaşma: 1 Mart 2003 tezkeresi,” Erciyes Üniversitesi İktisadi ve Idari Bilimler Fakültesi Dergisi, no. 51 (2018): 21-38.

2 Füsun Türkmen, "Turkish-American Relations: A Challenging Transition," Turkish Studies 10, no. 1 (2009): 109-29;
} 
anti-Americanism in the Turkish public. ${ }^{3}$ Furthermore, the failure of the motion was an exception as it is the executive that principally conducts foreign policy in Turkey. With the exception of the March 1 motion, the GNAT had accepted all previous parliamentary motions that warranted the dispatching of Turkish troops abroad or the deployment of foreign troops on Turkey's territory. ${ }^{4}$

Turkey pursued an ambivalent policy in the period leading up to the March 1 motion. Turkish decision-makers initially abstained from participation in the war against Iraq alongside the United States and sought a peaceful settlement since a military intervention could undermine the territorial integrity of Iraq and thereby strengthen Kurdish groups seeking independence. They also expressed their concerns about a unilateral intervention by the United States and voiced their concerns regarding international legitimacy. ${ }^{5}$ Under pressure from the global superpower, and within a limited time frame covering the period from December 3, 2002, to March 1, 2003, however, Turkish decision-makers changed their position. Systemic factors and the urgency of the issue led the newly-elected AK Party government to align with the United States. The domestic political environment was favorable for the ruling party to implement its decision as it had the majority in the GNAT and held key posts in the state structure. Nevertheless, it failed to get the March 1 motion approved. Though systemic factors were clear and demanded urgent action, the issue divided the AK Party, which made the GNAT the decisive agent in the decision process. Consequently, the formal research questions of the study are, 1) Which factors led the government to change its approach to the issue, and 2) Why did a government that had a favorable position in domestic politics fail to carry out its decision?

This study deals with the questions above from the perspective of neoclassical realism, which analyzes the interaction between systemic and unit-level variables. The study has two primary purposes. The first is to prove that in restrictive international environments where opportunities and threats are clear and the decision-making process is constrained by time, domestic divisions may matter in foreign policy and prevail over the systemic imperative, contrary to conventional expectations. Turkey, which may be classified as a secondary state in the regional context, encountered a restrictive international milieu. The unipolar international system and aggressive policies of the United States, Turkey's geographical proximity to Iraq, the distribution of power in the Middle East and the nature of bilateral relations between Turkey and the United States restricted the former's foreign policy options. Under these conditions, the Turkish government decided to align with the global hegemon. However, the final foreign policy decision did not reflect the system-level urgency. This brings us to the second purpose of the article, which is to demonstrate that in a restrictive international milieu, strong leadership, a factor underappreciated by neoclassical realists, is essential even for single-party governments, which are normally expected to have greater autonomy in

Mustafa Türkeş, "NATO bağlamında ABD-Türkiye ilişkilerinde devamlılık ve değişim," in Türk diş politikasının analizi, 3rd ed., ed. Faruk Sönmezoğlu (İstanbul: Der, 2004), 379-403; Şaban Kardaş, "Turkish-American Relations in the 2000s: Revisiting the Basic Parameters of Partnership?" Perceptions 16, no. 3 (2011): 25-52.

3 Füsun Türkmen, "Anti-Americanism as a Default Ideology of Opposition: Turkey as a Case Study," Turkish Studies 11, no. 3 (2010): 329-45; Omer Goksel Isyar, "An Analysis of Turkish-American Relations from 1945 to 2004: Initiatives and Reactions in Turkish Foreign Policy," Alternatives: Turkish Journal of International Relations 4, no. 3 (2005): 21-52; Nasuh Uslu, Çatlak ittifak: 1947'den günümüze Türk-Amerikan ilişkileri (Ankara: Nobel, 2016).

4 Çağrı Erhan and Ersin Embel, “Türk Dış Politikasında Karar Vericileri Yönlendiren Yapısal Faktörler,” BILLIG, no. 72 (2015): 145-170.

5 Ramazan Gözen, “Causes and Consequences of Turkey's Out-Of-War Position in the Iraq War of 2003," Turkish Yearbook of International Relations no. 36 (2005): 74-99. 
democratic parliamentary systems, to formulate foreign policy. The systemic and structural factors would have led the Turkish government to participate in the war against Iraq alongside the United States. Nevertheless, the top leadership, albeit in favor of aligning with the global hegemon, could not display a firm and resolute stance during the process. The lack of strong leadership crystalized the divisions in the AK Party, weakened the government's control over foreign policy and disrupted the harmony between state organs. For this reason, the GNAT played a decisive role in the foreign policy of Turkey.

\section{Explaining Turkey's Iraq War Decision}

Turkey's Iraq War decision has been analyzed within the framework of various perspectives. It is mostly framed in terms of domestic politics and decision-making theories. In some studies, it is claimed that the Islamic background of the AK Party precluded the collaboration with the United States in the war against a Muslim-populated country, and the GNAT rejected the March 1 motion. ${ }^{6}$ Such an approach has some defects. The party sought the support of the United States before the general election held on November 3, 2002, ${ }^{7}$ and even though it was more attentive and vigilant towards Middle Eastern affairs than previous governments, ${ }^{8}$ it embraced a multi-dimensional and pragmatic foreign policy. ${ }^{9}$ The leadership of the AK Party also gave priority to the national interest of Turkey in conducting foreign policy, rather than adopting an ideological-ideational discourse. ${ }^{10}$ Other studies highlight the role of the media $^{11}$ as well as public opinion in influencing the parliamentary decision. ${ }^{12}$ These studies emphasize that the GNAT was vulnerable to public pressure and its members voted as they preferred since the executive was indecisive about the motion. The media and public may affect foreign policy, especially in democratic states. ${ }^{13}$ Nevertheless, their effect is primarily indirect and not enough to explain specific foreign policy actions. ${ }^{14}$ Moreover, the influence of civil society on foreign policy is marginal in Turkey. ${ }^{15}$ Studies that deal with the issue within the framework of decision-making or decision-unit approaches have profound findings ${ }^{16}$ but were not made with reference to the distinct realm of international politics. Additionally, these studies are not a substitute for systemic and domestic explanations of foreign policy. ${ }^{17}$

\footnotetext{
Hasan B. Yalçın, "Making Sense of 1 March: A Proactive Strategy of Avoidance," Perceptions 18, no. 1 (2013): 158.

"ABD'lilerin duymak istediklerini söyledi," (editorial), Milliyet, January 30, 2002; Derya Sazak, "Erdoğan ikiz kuleler değişimi," Milliyet, February 2, 2002.

8 Kemal İnat and Burhanettin Duran, “AKP dış politikası: teori ve uygulama," in AK Partili yıllar, ed. Zeynep Dağı (Ankara: Orion, 2006), 15-70.

9 İlhan Uzgel, "Dış politikada AKP: Stratejik konumdan stratejik modele," in AKP kitabl: Bir dönüşümün bilançosu, ed. Bülent Duru and İlhan Uzgel (Ankara: Phoenix, 2010), 11-39.

10 Şaban Kardaş, “Türkiye ve Irak krizi: Kimlikle çıkar arasında AKP," in AK Parti toplumsal değişimin yeni aktörleri, ed. Hakan Yavuz (İstanbul: Kitap, 2010), 359-89.

${ }_{11}$ İpek Özlem, "Türk dıș politikasında medyanın etkisi: 1 Mart 2003 tezkeresi” (Unpublished Master thes., Yeni Yüzyıl University, 2018).

12 Baris Kesgin and Juliet Kaarbo, "When and How Parliaments Influence Foreign Policy: The Case of Turkey's Iraq Decision," International Studies Perspectives 11, no. 1 (2010): 19-36.

13 Lester W. Milbrath, "Interest Groups and Foreign Policy," in Domestic Sources of Foreign Policy, ed. James N. Rosenau (New York: Free, 1967), 231-51; Thomas Risse-Kappen, "Public Opinion, Domestic Structure, and Foreign Policy in Liberal Democracies," World Politics 43, no. 4 (1991): 479-512.

14 Robert H. Trice, "Foreign Policy Interest Groups, Mass Public Opinion and the Arab-Israeli Dispute," The Western Political Quarterly 31, no. 2 (1978): 238-52.

15 Abdullah Akyüz, "Türk-Amerikan ilişkilerinde sivil toplum kuruluşlarının rolü," in Sivil toplum ve diş politika: Yeni sorunlar, yeni aktörler, ed. Semra Cerit Mazlum and Erhan Doğan (İstanbul: Bağlam, 2007), 209-33.

16 Fatma Anıl Öztop, "Karar birimi kuramı çerçevesinde Türk dış politikasının analizi: 1 Mart 2003 tezkeresi örneği," Uluslararası Politik Araştırmalar Dergisi 1, no. 2 (2015): 33-45; and Türk dış politikası yapım sürecinde karar birimlerinin etkileri (İstanbul: Gündoğan, 2018). Zeynep Taydaş and Özgür Özdamar, "A Divided Government, an Ideological Parliament, and an Insecure Leader: Turkey's Indecision About Joining the Iraq War,” Social Science Quarterly 94, no. 1 (2013): $217-41$.

17 Taydaș and Özdamar, "A Divided Government," 220.
} 
Sensitive to the dynamic interaction between political leadership and international and domestic structures, some studies propose that leaders' personality traits influence foreign policy choices in similar international and domestic structural constraints. For instance, the literature has compared President Turgut Özal's 1991 Iraq War decision with that of the leader of the AK Party, Recep Tayyip Erdoğan, in the 2003 Iraq War. ${ }^{18}$ However, despite similarities, the international and domestic structures in the two crises differ from each other in certain respects. Moreover, placing personality traits at the fore misses the crucial point that favorable political conditions are a precondition for exercising decisive individual leadership. The AK Party government's specific attitude to the March 1 motion, therefore, merits investigation.

Other studies that use structural analyses have suggested that Turkey pursued soft balancing strategies against the United States during the crisis. These studies assert that American preponderance in the international system made internal or external balancing policies prohibitively expensive for balancers, which is why Turkey embraced a soft balancing strategy. ${ }^{19}$ Soft balancing offers a sound analytical lens to understand Turkey's foreign policy with respect to the Iraq War. However, such a rendering will not be able to illuminate some points. Did Turkish decision-makers, for instance, really believe that they could balance and persuade the United States to opt for a peaceful solution that structurally stronger states such as France, Germany, Russia, and China could not? More importantly, why did the government submit a new motion to the GNAT on March 20, 2003 ?

Turkey's Iraq War decision should be handled by considering the joint interaction between systemic and unit-level variables. Therefore, analyzing the issue within the framework of neoclassical realism, which introduces a holistic and comprehensive methodology to foreign policy analysis without ignoring the distinctive characteristics of international politics, may present opportunities for further understanding the foreign policy of Turkey during the crisis and yield instructive inferences for future studies in the neoclassical realist research agenda as well as Turkish foreign policy.

\section{A Neoclassical Realist Explanation of Foreign Policy}

As one of the variations in the realist theory of international relations, neoclassical realism essentially emerged as a reaction to criticisms against structural realism. It aims to increase the explanatory power of realism by introducing domestic variables without losing the primary insights of structural realism to explain power relations in international politics.

Neoclassical realism rests on the systemic basis of structural realism yet also considers "the complex relationship between state and society found in classical realism. ${ }^{\prime 20}$ Neoclassical realists accept the international system as the chief variable determining the actions of states. They also argue, however, that states' evaluation of system-level power relations is not a smooth process since state officials may not properly comprehend the distribution of power in international politics. Hence, neoclassical realism primarily deals with the foreign policy

\footnotetext{
18 Esra Cuhadar, Juliet Kaarbo, Baris Kesgin, and Binnur Ozkececi-Taner, "Examining Leaders' Orientations to Structural Constraints: Turkey's 1991 and 2003 Iraq War Decisions," Journal of International Relations and Development 20 (2017): 29-54.

19 Murat Yeşiltaş, "Soft Balancing in Turkish Foreign Policy: The Case of the 2003 Iraq War," Perceptions 14, no. 1 (2009): 25-51; and "Peşine takılma mı yumuşak dengeleme mi? Türkiye'nin Birinci ve İkinci Irak Savaşına yönelik ABD ile müttefiklik ilişkisinin karşılaştırmalı analizi," in Mekân, kimlik, güç ve dış politika, ed. S. Gülden Ayman (İstanbul: Yalın, 2012), 69-110.

20 Jeffrey W. Taliaferro, Steven E. Lobell, and Norrin M. Ripsman, "Introduction: Neoclassical Realism, the State, and Foreign Policy," in Neoclassical Realism, the State, and Foreign Policy, ed. Steven E. Lobell, Norrin Ripsman, and Jeffrey W. Taliaferro (Cambridge: Cambridge University, 2009), 23.
} 
of states on two variables: the international system as the independent variable and domestic politics as the intervening variable. The system-level signals from the international system are filtered by unit-level variables such as leaders' images of world politics, strategic culture, state-society relations, and domestic institutions. ${ }^{21}$

There is a thriving literature on neoclassical realism due to the eclectic and pragmatic nature of the approach, which offers a practical framework for analyzing foreign policy. ${ }^{22}$ Its eclecticism has also made neoclassical realism a target for some scholars. ${ }^{23}$ While it is beyond the scope of this article to discuss the controversies surrounding the approach, it is necessary to understand how scholars have sought to utilize the framework to better articulate this study's contribution. According to the classification elaborated by Ripsman et al., the neoclassical realist literature may be identified with two distinct types of research. Type I neoclassical realism is aimed at ameliorating the shortcomings of structural realism by employing domestic-level variables. It mainly handles the cases in which states inappropriately respond to the systemic imperative. Type II seeks to explain foreign policy choices and grand strategic adjustments. Studies in this category basically argue that states have more policy options when there are no clear and imminent threats in the international system. Ripsman et al. also carve out a third type with the purpose of forging a theory of international politics. They claim that neoclassical realism may explain international outcomes and systemic change, which are affected by states' policy choices. ${ }^{24}$

This study seeks to explicate which factors had a major effect on steering the foreign policy of Turkey towards the March 1 motion process. It suggests unipolarity as the systemic imperative and geography as the structural modifier primarily directing Turkey's attitude. In a unipolar international system, Turkey faced the pressure of the superpower, and its decision-makers acceded to the demands of the United States. Moreover, Turkey's geographical proximity to Iraq and the possibility of the emergence of a Kurdish state in northern Iraq affected the decision calculus. Therefore, the international systemic signals and geography, the effects of which may objectively be observed in the statements of Turkish decision-makers, compelled Turkey to side with the United States. Additionally, the regional features of the Middle East as a sub-systemic factor and the nature of the bilateral relations between Turkey and the United States had a constraining influence on Turkey. Under these circumstances, the AK Party government adopted a kind of bandwagoning policy so as not to confront the superpower and to have a say in the region after the war.

The systemic factor and structural modifier specified above chiefly conditioned Turkey's position. Nevertheless, the AK Party government was impeded by domestic politics. For this reason, unit-level elements require elaboration. First of all, the present theory identifies key decision-makers as the foreign policy executive (FPE). Foreign policy is primarily conducted by the executive, particularly by the government. In principle, the president, prime minister,

${ }^{21}$ Gideon Rose, "Neoclassical Realism and Theories of Foreign Policy," World Politics 51, no. 1 (1998): 144-72. Taliaferro, et al., "Introduction: Neoclassical Realism," 1-42.

22 Gustav Meibauer, Linde Desmaele, Tudor Onea, Nicholas Kitchen, Michiel Foulon, Alexander Reichwein, and Jennifer Sterling-Folker, "Forum: Rethinking Neoclassical Realism at Theory's End," International Studies Review (2020): 1-28, doi: /10.1093/isr/viaa018.

23 Jeffrey W. Legro and Andrew Moravcsik, "Is Anybody Still a Realist?," International Security 24, no. 2 (1999): 5-55; John A. Vasquez, "The Realist Paradigm and Degenerative versus Progressive Research Programs: An Appraisal of Neotraditional Research on Waltz's Balancing Proposition," The American Political Science Review 91, no. 4 (1997): 899-912; Kevin Narizny, "On Systemic Paradigms and Domestic Politics: A Critique of the Newest Realism," International Security 42, no. 4 (2017): 155-90.

24 Norrin M. Ripsman, Jeffrey W. Taliaferro, and Steven E. Lobell, Neoclassical Realist Theory of International Politics (Oxford: Oxford University, 2016). 
key cabinet members, ministers, especially the minister of foreign affairs, and foreign policy advisors are charged with formulating foreign and defense policies. ${ }^{25}$ Yet, the FPE is not free from domestic impediments. ${ }^{26}$ In other words, it is not totally autonomous in implementation of foreign policy. Institutional structures, decision-making procedures, and procedural norms are the most significant indicators of foreign policy autonomy (FPA), which "refers to the structural capacity of the foreign policy executive to pursue policies when faced with public or legislative opposition. ${ }^{\text {27 }}$ Additionally, a government's vulnerability may affect its autonomy. The likelihood of whether the current leadership is removed from political office specifies the degree of vulnerability. ${ }^{28}$ Autonomy and vulnerability are essential variables for this study since a single-party government that possessed key governmental posts could not manage to implement its foreign policy decision even though it had a sufficient parliamentary majority.

The study draws on the variables specified above to analyze Turkey's foreign policy disposition. However, some points need further elaboration. Firstly, realism in general and neoclassical realism in particular are criticized on account of the fact that they mainly deal with great power politics. In fact, as power is the basis of the realist tradition, great powers are prominently featured in the realist literature. Nevertheless, this does not mean that neoclassical realism has little relevance to the strategic behaviors of middle and small powers. From the perspective of neoclassical realism, it is essential to investigate how these states may react to a unipolar international environment in which the United States embraced unilateral policies. ${ }^{29}$ In this sense, this study may be fruitful since Turkey is generally regarded as a regional middle power. ${ }^{30}$ The exact nature of Turkey's international political status requires comprehensive research that is beyond the aim of this article. Drawing on Lobell et al., ${ }^{31}$ it may be proposed here that Turkey is a secondary state in the regional context. It cannot single-handedly and directly affect the distribution of power in the international system but can influence international politics by forging alliances with enough number of states.

Secondly, neoclassical realism incorporates systemic and unit-level variables yet offers little insight about how to construct the interaction between them..$^{32}$ It is uncertain in what circumstances which level carries more weight in the conduct of foreign policy. In general, the theory predicts that permissive international environments present more policy options for decision-makers while restrictive ones have a constraining effect on states and diminish the influence of domestic divisions on foreign policy, especially in times of crisis.

\footnotetext{
25 Ripsman et al., Neoclassical Realist Theory, 61.

26 Norrin M. Ripsman, “Neoclassical Realism and Domestic Interest Groups," in Lobell, Ripsman, and Taliaferro, Neoclassical Realism, $172-74$.

7 Norrin M. Ripsman, Peace-Making by Democracies: The Effect of State Autonomy on the Post-World War Settlements (Pennsylvania: The Pennsylvania State University, 2002), 43-57.

28 Randall L. Schweller, “Unanswered Threats: A Neoclassical Realist Theory of Underbalancing," International Security 29, no. 2 (2004): 173-75.

29 Norrin M. Ripsman, Jeffrey W. Taliaferro, and Steven E. Lobell, "Conclusion: The State of Neoclassical Realism," In Lobell, Ripsman, and Taliaferro, Neoclassical Realism, 295-96; Ripsman et al., Neoclassical Realist Theory, 185-86.

30 Emel Parlar Dal, "Conceptualising and Testing the 'Emerging Regional Power' of Turkey in the Shifting International Order," Third World Quarterly 37, no. 8 (2016): 1425-453; Hasan B. Yalçın, "The Concept of "Middle Power" and the Recent Turkish Foreign Policy Activism," Afro Eurasian Studies 1, no. 1 (2012): 195-213.

${ }_{31}$ On the basis of David R. Mares's classification of states in the international system, Lobell et al. examine why secondary and tertiary states support, follow or challenge the regional rising states, such as Brazil, India, China, and South Africa. Mares makes a four-fold distinction on the position of states in the international system, drawing on structural realist theory. He classifies states as great, secondary, middle, and small ones. In this classification, secondary and tertiary states of Lobell et al. in the regional context basically equate middle and small states to secondary and tertiary states, respectively. Steven E. Lobell, Neal G. Jesse, and Kristen P. Williams, "Why Do Secondary States Choose to Support, Follow or Challenge?," International Politics 52, no. 2 (2015): 146-62.

32 Ali Balci, Tuncay Kardaş, İsmail Ediz, and Yildirim Turan, "War Decision and Neoclassical Realism: The Entry of the Ottoman Empire into the First World War," War in History (2018): 1-28, doi: 10.1177/0968344518789707.
} 
When opportunities and threats in the international system are clear, variances for optimal policy choices among societal actors are low. ${ }^{33}$ From this perspective, the March 1 motion offers many complexities as domestic divisions in Turkey became evident in a restrictive international milieu, and the ruling majority government was unable to formulate and implement a coherent policy.

Third, though assumed to be unified, the FPEs may be divided ${ }^{34}$ or ambivalent. In such cases, bodies or individuals that are not directly in charge of conducting foreign policy may function as the FPE. Thus, especially in a restrictive international milieu, even for single-party governments, strong leadership may be required for proper translation of systemic signals as well as the achievement of coordination between state organs for a consistent foreign policy response..$^{35}$ An influential and resolute leader may facilitate the implementation of a hierarchical decision-making procedure and thereby promote the FPA of governments. In fact, the ambivalent attitude of the AK Party's top leadership on the issue led to the loss of control of the government over foreign policy and disrupted the coordination between state organs, resulting in a foreign policy response by Turkey inconsistent with the expectations of conventional neoclassical realist assumptions.

\section{The Iraq Issue in Turkish Foreign Policy}

The Iraq issue entered the Turkish political agenda long before the AK Party came to power. When Saddam Hussein occupied Kuwait in August 1990, Turkey allied with the coalition states against Saddam. The military intervention changed the domestic political order of Iraq, and the control of the central government over Iraqi territory weakened. Therefore, the future of the country and the rising influence of the Kurdish groups in northern Iraq became a security matter for Turkey throughout the 1990s.

The 9/11 attacks ignited the Iraq issue again. Turkish decision-makers condemned the attacks and stated that Turkey would support the United States' efforts against the war on terror. The coalition government took permission from the GNAT to deploy Turkish troops abroad, and Turkey provided logistic support and training to Afghan personnel. However, the attitude of the decision-makers towards a military intervention in Iraq was different. They were anxious that the intervention could lead to the dissolution of Iraq, and a Kurdish state might emerge. Staying out of the war against Iraq was therefore the preferred policy of Turkey's coalition government. ${ }^{36}$

Shortly before the March 1 decision, Turkey held a general election that resulted in the emergence of a new political actor, the AK Party. The fact that a single party came to power enabled the United States to cooperate with a more unified cabinet and legislature. Thus, American officials swiftly contacted the new government. Three actors from Turkey actively participated in the process. The first was the head of the government, Prime Minister Abdullah Gül. The second was the influential leader of the AK Party, Recep Tayyip Erdoğan, who was banned from politics. Gül and Erdoğan were the key decision-makers in charge of Turkey's policy response. Though less effective, the Minister of Foreign Affairs, Yaşar Yakış,

\footnotetext{
33 Ripsman et al., Neoclassical Realist Theory, 52-8

34 Balci et al., "War Decision and," 1-28.

35 See for a discussion Ariel Ilan Roth, Leadership in International Relations: The Balance of Power and the Origins of World War II (New York: Palgrave Macmillan, 2010).

36 Samet Yılmaz, "Neoklasik realizm ve dış politika: 1 Mart tezkeresi örneği”" (Unpublished Master thes., Uludağ Üniversitesi, Bursa, Turkey, 2014), 64-7.
} 
was included as the third actor.

The United States made first contact with the new government on December 3, 2002. United States Deputy Secretary of Defense Paul Wolfowitz and Undersecretary of State for Political Affairs Marc Grossman arrived in Ankara. Wolfowitz stated that the United States expected Turkey's full and complete cooperation. He offered a three-phased plan to Gül. In the first stage, the American military officials would inspect the communication facilities and military bases in Turkey. Second, the condition of these facilities and bases would be improved. Third, the American and English land and air forces would be stationed in Turkish territory, when necessary, to be employed in the war against Iraq. ${ }^{37}$

Though the AK Party government had its own modus operandi and agenda, its approach to the issue was not different from its predecessor's. It was anxious that the intervention could fuel the aspirations of Kurdish separatists to pursue autonomy or establish a Kurdish state and result in economic losses for Turkey. ${ }^{38}$ Thus, Turkey implemented multilateral and bilateral initiatives to find a peaceful settlement in January 2003. ${ }^{39}$ If the intervention was to be carried out, it was supposed to be in cooperation with the international community. However, international political developments rendered it difficult for Turkey to adopt a normative or principled stance towards the issue..$^{40}$

\section{One Option for Turkey in a Unipolar World}

The government initially abstained from formally allying with the United States in the war against Iraq, yet American demands were gradually included in the Turkish political agenda. Two of three among these demands were approved with the February 6 motion. ${ }^{41}$ So, the government gradually shifted from a cautious and non-committal approach to a position in line with systemic and structural factors. The systemic factors that forced Turkey to change its position were the unipolar structure of the international system and the inclination of the American executive to turn the national power of the United States into influence on international politics. With the collapse of the Soviet Union, the United States remained the sole superpower. Despite occasional objections, there was no open challenge to American supremacy. ${ }^{42}$ The Bush administration declared the will of the United States to impose a new world order and act unilaterally if need be..$^{43}$ While the United Kingdom supported the invasion of Iraq, other key allies, like France and Germany, were critical. Russia and China were also opposed to the operation but could not affect the United States. American officials declared that they would strike Iraq even without the support of their allies. ${ }^{44}$ So, any kind

37 Murat Yetkin, Tezkere: Irak krizinin gerçek öyküsü, 2nd ed. (İstanbul: Remzi, 2004), 98-101.

38 Gözen, "Causes and Consequences," 74-99.

39 Y1lmaz, "Neoklasik realizm," 95-6.

40 Sevilay Z. Aksoy, "The Turkish Stance Toward the US Requests for the 2003 Iraq War: A Case of Norms Versus Interests?," Ortadoğu Etütleri 10, no. 2 (2018): 8-47.

41 Yilmaz, "Neoklasik realizm," 102-05.

42 The article takes Wohlforth and Brooks's statements on the structure of international system after the Cold War as a reference. They claim that the national capacity of the United States shows how dominant it is. No country is ever close to the United States in terms of political, economic, and military power. It is the leader in all areas, which is unprecedented in history. Thus, the international system following the Cold War is certainly unipolar. William C. Wohlforth, "Stability of a Unipolar World," International Security 24, no. 1 (1999): 5-41; William C. Wohlforth and Stephen Brooks, "American Primacy in Perspective," Foreign Affairs 81, no. 4 (2002): 20-33; and World Out of Balance: International Relations and the Challenge of American Primacy (Princeton, N.J.: Princeton University, 2008).

43 Colin Dueck, "Ideas and Alternatives in American Grand Strategy, 2000-2004," Review of International Studies 30, no. 4 (2004): 511-35; Janothan Monten, "Primacy and Grand Strategic Beliefs in US Unilateralism," Global Governance 13, no. 1 (2007): $119-38$.

44 "US Will Attack without Approval 'Zero Tolerance' Policy by Bush Administration,” November 11, 2002, accessed June 11, 
of balancing behavior seemed useless and costly. Turkey had already taken notice of this situation. The Turkish Embassy in Washington had warned the Ministry of Foreign Affairs before the general election and stated that the United States would strike Iraq even without a United Nations resolution. ${ }^{45}$ Hence, three options emerged for Turkish FPEs. Turkey would either ally with the United States, stay out of the conflict, or act unilaterally by sending its troops to northern Iraq.

Turkey chose the first option. The FPEs thought that Turkey "faced with the painful central reality of the unipolar structure" 46 could not stop the war, and the other options would lead to confrontation with the United States. This conviction could be observed in the various remarks of the FPEs. Gül said on February 5 that Turkey had done everything to find a peaceful way, and the responsibility was now in Saddam's hands. Turkey could not stay out of the issue and should act together with the United States. ${ }^{47}$ Before the vote on the February 6 motion, Erdoğan attempted to persuade AK Party deputies to support the motion, underscoring that no country could challenge the United States. ${ }^{48}$ Yakış, meanwhile, also stated that when it was understood that the war was unavoidable and Turkey could not stop it, the government considered siding with the United States. ${ }^{49}$

In addition to the unipolar international moment, the geographical proximity of the conflict forced the government to cooperate with the United States. Turkish officials postulated that the emergence of a Kurdish state in northern Iraq, the fall of Mosul and Kirkuk into the hands of Kurdish groups, the strengthening of the Kurdistan Workers' Party (PKK), and the fate of the Turkomans were Turkey's redlines. ${ }^{50}$ The PKK factor was notably critical. The Turkish military performed many cross-border operations throughout the 1990s to protect Turkey's southern borders. ${ }^{51}$ In fact, Erdoğan warned the AK Party parliamentary group before the vote on the March 1 motion that if Turkey did not act with the United States, a Kurdish state could emerge in northern Iraq, and separatist activities in Turkey could rise again. ${ }^{52}$

The regional characteristics of the Middle East and the nature of Turkey's relations with the United States also restricted the AK Party government. The Middle East is a dynamic and unstructured region. There is no state in the region, such as China, Russia, or India, that has the capacity to claim regional supremacy. The absence of a regional hegemonic power makes the Middle East more vulnerable to external intervention and penetration. ${ }^{53}$ Therefore, Turkey could not rely on the states in the region to balance the United States. Moreover, the United States has been strategically engaged with Middle Eastern politics since the mid-1950s, and its policies have an impact on the national security of the states in the region. Consequently, security has been the basic variable determining the bilateral relations between Turkey and

\footnotetext{
2019. https://www.theguardian.com/world/2002/nov/11/iraq.usa

45 Öztop, Türk diş politikası, 231.

46 Yalçın, "Making Sense of," 176.

47 Murat Yetkin, “Irak'ta ABD'nin yanındayız," Radikal, February 6, 2003.

48 “Irak tezkeresi AKP'yi çatlatt1," (editorial), Milliyet, February 7, 2003.

49 Özgür Özdamar, "Dış politika karar alımı sürecinde lider merkezli yaklaşım: akılcı tercih kuramı ve Türkiye'nin Irak Savaşı'na katılmama kararı," in Dış politika teorileri bağlamında Türk dış politikasının analizi, ed. Ertan Efegil and Rıdvan Kalaycı (Ankara: Nobel, 2012), 488.

50 Fikret Bila, Ankara'da Irak savaşlart: Sivil darbe girişimi ve gizli belgelerle 1 Mart tezkeresi, 6th ed (İstanbul: Güncel 2007), 225.

51 Özlem Tür, “Türkiye'nin Irak ve Suriye ilişkileri,” in XXI. yüzyılda Türk dış politikasının analizi, ed. Faruk Sönmezoğlu, Nurcan Özgür Baklacioğlu, and Özlem Terzi (İstanbul: Der, 2012), 595-98.

52 Öztop, Türk diș politikası, 262.

53 Anoushiravan Ehteshami, "Middle East Middle Powers: Regional Role, International Impact," Uluslararası İlişkiler 11, no. 42 (2014): $29-49$.
} 
the United States, ${ }^{54}$ and the security consequences of the Iraq issue also compelled Turkish decision-makers to collaborate with the United States.

Turkey failed to follow a consistent and stable policy during the crisis. It was in favor of preserving the status quo and peacefully resolving the issue at the outset as the war might lead to destabilization of the region. But, when the FPEs saw that the United States would strike Iraq and an international consensus was not reached, they concluded that Turkey had to align with the United States. Furthermore, the geographical proximity and the regional distribution of power in the Middle East undergirded this conviction. So, suggesting that Turkey adopted a kind of bandwagoning policy in order to have a say in reshaping the region seems telling. As bandwagoning is more feasible when faced with states that have greater capabilities and aggressive intentions, ${ }^{55}$ the government decided to cooperate with the United States due to the difficulties in balancing the superpower. Whether Turkey embraced a defensive (status quo) or aggressive bandwagoning policy is unclear. However, it may be argued that the government pursued a jackal and piling-on bandwagoning policy in Schweller's terms ${ }^{56}$ to a certain degree. It was almost certain that the United States would prevail over Iraq. The government avoided confronting the United States and sought to share the spoils of war to protect the national security of Turkey and increase its influence over the region.

\section{Why the AK Party Government Failed}

The March 1 motion, which would allow the deployment of up to 62,000 foreign troops on Turkey's territory and the dispatching of Turkish troops abroad, was submitted to the GNAT on February 25. It did not pass due to the small margin of approving votes on March 1. In principle, the government had a high degree of autonomy. The AK Party was the majority in the GNAT and held all executive posts at the ministerial level. Furthermore, it had just won the general election, which gave it democratic legitimacy. Thus, the government was less vulnerable to removal from power. Nevertheless, it failed to get the motion through. It may be proposed that two reasons account for this.

The first and the most significant one was the ambivalence of the leadership. Gül and Erdoğan were in favor of the motion, but they faced some constraints and assumed different roles. As prime minister, Gül was politically and legally beholden to the public opinion. Therefore, he was more cautious and always responsive to other options. ${ }^{57}$ Furthermore, as Erdoğan would take over the prime ministry, it was stated in the press that Gül's advisors recommended him to be cautious. ${ }^{58}$ Similarly, Erdoğan, too, was constrained. He had a great influence on the party, which is why the United States' officials interacted more with him than Gül during the process. ${ }^{59}$ The fact that Erdoğan was out of the GNAT and did not have an official post, however, limited his influence. He was negotiating a constitutional amendment to be elected as prime minister and was then preparing for interim elections to be held on March 9, 2003. Erdoğan seemed to be in a quandary. If he forced the deputies, the party could

${ }^{4}$ Türkmen, "Turkish-American Relations," 109-29.

55 Stephen M. Walt, "Alliances: Balancing and Bandwagoning," in International Politics: Enduring Concepts, and Contemporary Issues, 13th ed., ed. Robert J. Art and Robert Jervis (New York: Pearson, 2016), 159-60.

56 Randall L. Schweller, "Bandwagoning for Profit: Bringing the Revisionist State Back in," International Security 19, no. 1 (1994): 93-6.

57 Ahmet Sever, Abdullah Gül ile 12 yll: Yaşadım, gördüm, yazdım (İstanbul: Doğan Kitap, 2015), 38-47.

58 Bila, Ankara'da Irak savașları, 213.

59 Marina E. Henke, "The Rotten Carrot: US-Turkish Bargaining Failure Over Iraq in 2003 and the Pitfalls of Social Embeddedness," Security Studies 27, no. 1 (2018): 120-47. 
be divided, and he could lose his authority over the party. If he went against the United States, he could lose his international support. ${ }^{60}$

The ambivalence of the leadership paved the way for external penetration and the dissolution of the AK Party. The United States' officials held informal meetings with those who were not officially liable for conducting foreign policy but were influential within the ruling party, such as Ömer Çelik, Cüneyd Zapsu, and Egemen Bağış. ${ }^{61}$ They were among Erdoğan's consultants and gave utmost importance to Turkey's relations with the United States. Naturally, they favored the motion. ${ }^{62}$ So, the coordination between the FPEs was disrupted. Moreover, since no actor was able to act as a predominant leader, a hierarchical, or in other words, ordinary decision-making procedure could not be implemented. ${ }^{63}$ The party discipline disappeared, and the motion was sent to the GNAT without a party group decision. The urgency of the issue concretized the divisions in the AK Party, which was composed of diverging political tendencies. ${ }^{64}$ Some members of the party, such as Murat Mercan and Ahmet Davutoğlu, who were among Gül's advisors, believed that Turkey should develop a multi-dimensional foreign policy and establish good relations with its neighbors, even at the expense of harming relations with the United States. ${ }^{65}$ Cabinet members also had opposing views on the motion. ${ }^{66}$ During the plenary session in which the motion was negotiated in the GNAT, Önder Sav's speech on behalf of the main opposition party seemed to have a negative effect on the already hesitant deputies of the AK Party ${ }^{67}$ Hence, as Erdoğan said on May 26, 2007 , the party was divided concerning the motion. ${ }^{68}$

Second, governmental control over the bureaucracy was weak. There were two reasons for this situation. The first was that the AK Party was a new one, founded on August 14, 2001. It could not yet establish control over the civil bureaucracy, which had acted as an organized and influential agent since the foundation of the Republic of Turkey. ${ }^{69}$ The government faced this ossified state system after the general election. The second was the AK Party's political background. Its founders mostly came from the Welfare Party (WP), which resigned from government after the military memorandum on February 28, 1997, and which was closed by the Constitutional Court on account of its anti-secular actions. The successor of the WP, the Virtue Party (VP), was also shut down by the Court in June 2001. After these developments, a new clique from the VP referred to by the media as 'reformists' formed the AK Party. The founders expressed that they changed their political stance. Because of its Islamist origins, however, the party had strains with the military and civil bureaucracy. ${ }^{70}$

Its limited control over the bureaucracy led the AK Party to benefit from its political advisors, rather than the bureaucracy, in the conduct of foreign policy. Advisors were especially influential in the early tenure of the government. Hence, the bureaucracy and politicians were disunited. While the negotiations with the United States were on going, the

60 Özdamar, "Dış politika karar," 494-97.

${ }^{61}$ Bila, Ankara'da Irak savaşları, 186-88; Yetkin, Tezkere: Irak krizinin, 103-04.

62 İnat and Duran, "AKP diş politikası," 40.

63 Öztop, "Karar birimi kuramı," 33-45.

64 Kardaş, "Türkiye ve Irak,", 379-93.

65 İnat and Duran, "AKP diș politikası," 41

66 Y1lmaz, "Neoklasik realizm," 114.

67 Y1lmaz, "Neoklasik realizm," 109-11.

68 Deniz Bölükbaşı, 1 Mart vakast: Irak tezkeresi ve sonrası, 4th ed. (İstanbul: Doğan Kitap 2008), 136.

69 Gökhan Tuncel, Sivil toplum ve devlet (Malatya: Bilsam, 2011), 99-173.

70 Garreth Jenkins, "Semboller ve gölge oyunu ordu-AKP ilişkileri 2002-2004," trans. Bayram Sinkaya, in AK Parti toplumsal değişimin yeni aktörleri, ed. Hakan Yavuz (İstanbul: Kitap, 2010), 235-57. 
lack of coordination between Yakış and the foreign affairs bureaucracy was observed in some cases. ${ }^{71}$ The lack of governmental control over the bureaucracy reduced the government's ability to steer information. In fact, the deputies of the AK Party were not even informed of the content of the memorandum of understanding between Turkey and the United States. ${ }^{72}$ Furthermore, the government attempted to share responsibility with other state organs. It waited for the National Security Council (NSC) meeting on February 28, 2003, and expected a decision to facilitate the approval of the motion by the GNAT. Then an influential advisory body, the NSC was liable for protecting the unity of the state and society against internal and external threats, ${ }^{73}$ but on this occasion did not make a recommendation as expected. ${ }^{74}$ Just like the AK Party, the commanders of the different branches of armed forces had divergent opinions on the March 1 motion..$^{75}$ Therefore, the responsibility for joining the war alongside the United States was left to the government, which was bereft of an authoritative leader.

The developments specified above impaired the harmony between state organs and decreased the government's influence on foreign policy. Thus, the GNAT became a significant agent in the process. It may be proposed that it almost functioned as the FPE. ${ }^{76}$ The fact that the leadership could not display a firm and coherent stance towards the March 1 motion made the GNAT a balancing actor. After the vote, the Chairman of the GNAT's Foreign Affairs Commission Mehmet Dulger stated that "a new motion...- should be presented in a different manner to Parliament and a strong-looking government with a stronger voice is also needed. "77 The approval of a new motion on March 20, 2003, after Erdoğan became prime minister on March 14, shows how important strong leadership is as a unifying factor, necessary for making coherent foreign policy decisions consistent with the requirements of the international system. ${ }^{78}$

\section{Conclusion}

Turkey displayed an unusual attitude and refused the demands of its close partner in a unipolar international structure. The AK Party government initially eschewed entering the war along with the United States. Then, it changed its initial position and embraced a kind of bandwagoning policy. This choice seems rather clear in view of prevalent systemic and geographical factors, and as neoclassical realists anticipate, ${ }^{79}$ Turkey's eventual decision was a reaction to the uncertainties that might emerge in its surrounding regions following the war. The government had a favorable domestic political environment for implementation of its decision, yet the ambivalence of the leadership and the weakness of governmental control over the bureaucracy debilitated the government's position. So, Turkey could not pursue an effective bandwagoning policy. Some conclusions may be drawn from the investigation.

First, it may be suggested that when encountering the aggressive policies and demands of a global hegemon, which may result in the destabilization of its surrounding regions,

Y1lmaz, "Neoklasik realizm," 90-3.

Bölükbaşı, 1 Mart vakası, 156.

Gencer Özcan, "Türkiye dış politikasında algılamalar, karar alma ve oluşum süreci," in Türk dış politikasının analizi, 13th ed., ed. Faruk Sönmezoğlu (İstanbul: Der, 2004), 850.

74 Bila, Ankara'da Irak savaşları, 217.

“Hilmi Özkök, tezkereyle ilgili bilinmeyenleri anlattı," (editorial), Hürriyet, August 6, 2012.

Kesgin and Kaarbo, "When and How," 19-36.

7 Kemal Balc1, "Dulger: Turkey Needs Government With Strong Voice," Turkish Probe, March 9, 2003 quoted in Kesgin and Kaarbo, "When and How," 32.

78 Kardaş, "Türkiye ve Irak," 384; Öztop, "Karar birimi kuramı," 42.

79 Rose, "Neoclassical Realism," 152. 
a secondary state primarily considers three variables while formulating its foreign policy: the attitude of the great powers in the international system towards the global hegemon, the regional distribution of power, and the degree of engagement of the global hegemon in the region. When the great powers are unable to deter the hegemon's aggressive intentions, it may be unwise and costly for the secondary state to pursue balancing. The fact that the global hegemon is strategically engaged in a region lacking a regional great power also precludes a balancing strategy. Furthermore, the nature of the bilateral relations between the secondary state and the global hegemon is significant for the strategies of the former. If security is at the core of bilateral relations, it is difficult for the secondary state to resist the hegemon. ${ }^{80} \mathrm{In}$ such cases, the secondary state may opt to bandwagon with the global hegemon to protect its national security and thereby enhance its influence over its surrounding regions.

Second, contrary to the neoclassical realist expectations, even when opportunities and threats in international politics are explicit, domestic actors may have the opportunity to articulate their alternative preferences particularly on national security matters. The study demonstrates that although the systemic messages were clear and discernible, the domestic divisions in Turkey had an influence on the decision-making process towards the March 1 motion. The systemic and structural factors, including time pressure, led to the emergence of a restrictive international milieu for Turkey. The FPEs concluded that Turkey had to cooperate with the United States. However, on this occasion the urgency of the issue concretized the divergences in domestic politics. As the international pressure increased, the cohesion of the ruling party and the coordination between state organs weakened. Therefore, domestic divisions prevailed over the systemic imperative in a restrictive international environment.

Third, especially during crisis periods in which decision-making is constrained by time, strong leadership is required to ensure coordination between state organs and promote the ability of the executive to perform a coherent foreign policy. Moreover, a strong leader decreases the disruptive effects of foreign penetration on the decision-making process. A predominant leader allows external actors to establish contact with a state through a single interlocutor with control over his or her milieu. This way, the executive may manipulate information about the developments in international politics, allowing better coordination between FPEs and the bureaucracy, promoting greater governmental control over the bureaucracy, and marginalizing alternative policy options. Therefore, it may be proposed that strong leadership, among other things, is one of the factors that determine the degree of governments' FPA even under majority governments. An influential decision-maker who can act with authority enables the articulation and implementation of a coherent foreign policy. In such cases, governments have more autonomy. This study shows that even though a single party had the majority, and institutional structures, decision-making procedures, and procedural norms favored the executive, the legislative virtually took on the function of the FPE due to the lack of strong leadership within the government.

\section{Bibliography}

Aksoy, Sevilay Z. "The Turkish Stance toward the US Requests for the 2003 Iraq War: A Case of Norms versus Interests?” Ortadoğu Etütleri 10, no. 2 (2018): 8-47.

Akyüz, Abdullah. "Türk-Amerikan ilişkilerinde sivil toplum kuruluşlarının rolü.” In Sivil toplum ve diş

\footnotetext{
80 See Lobell, et al., "Why Do Secondary," 146-62.
} 
politika: Yeni sorunlar, yeni aktörler, edited by Semra Cerit Mazlum and Erhan Doğan, 209-33. İstanbul: Bağlam, 2007.

Babacan, Abdurrahman. "AK Parti dönemi ilk küresel karşılaşma: 1 Mart 2003 tezkeresi." Erciyes Üniversitesi İktisadi ve İdari Bilimler Fakültesi Dergisi 51 (2018): 21-38.

Balci, Ali, Tuncay Kardaş, İsmail Ediz, and Yildirim Turan. "War Decision and Neoclassical Realism: The Entry of the Ottoman Empire into the First World War." War in History (2018): 1-28. doi: $10.1177 / 0968344518789707$.

Bila, Fikret. Ankara'da Irak savaşlart: Sivil darbe girişimi ve gizli belgelerle 1 Mart tezkeresi. 6th ed. İstanbul: Güncel, 2007.

Bölükbaş1, Deniz. 1 Mart vakası: Irak tezkeresi ve sonrası. 4th ed. İstanbul: Doğan Kitap, 2008.

Cuhadar, Esra, Juliet Kaarbo, Baris Kesgin, and Binnur Ozkececi-Taner. "Examining Leaders' Orientations to Structural Constraints: Turkey's 1991 and 2003 Iraq War Decisions." Journal of International Relations and Development 20 (2017): 29-54.

Dal, Emel Parlar. "Conceptualising and Testing the 'Emerging Regional Power' of Turkey in the Shifting International Order." Third World Quarterly 37, no. 8 (2016): 1425-453.

Dueck, Colin. "Ideas and Alternatives in American Grand Strategy, 2000-2004." Review of International Studies 30, no. 4 (2004): 511-35.

Ehteshami, Anoushiravan. "Middle East Middle Powers: Regional Role, International Impact." Uluslararası İlişkiler 11, no. 42 (2014): 29-49.

Erhan, Çağrı, and Ersin Embel. "Türk dış politikasında karar vericileri yönlendiren yapısal faktörler." BILIGG, no. 72 (2015): 145-70.

Gözen, Ramazan. "Causes and Consequences of Turkey's Out-Of-War Position in the Iraq War of 2003." Turkish Yearbook of International Relations 36 (2005): 74-99.

Henke, Marina E. “The Rotten Carrot: US-Turkish Bargaining Failure Over Iraq in 2003 and the Pitfalls of Social Embeddedness." Security Studies 27, no. 1 (2018): 120-47.

İnat, Kemal, and Burhanettin Duran. "AKP dış politikası: Teori ve uygulama.” In AK Partili yıllar, edited by Zeynep Dağı, 15-70. Ankara: Orion, 2006.

Isyar, Goksel Omer. "An Analysis of Turkish-American Relations from 1945 to 2004: Initiatives and Reactions in Turkish Foreign Policy.” Alternatives: Turkish Journal of International Relations 4, no. 3 (2005): 21-52.

Jenkins, Garreth. "Semboller ve gölge oyunu ordu-AKP ilişkileri 2002-2004." In Yavuz, AK parti, 235-57. Translated by Bayram Sinkaya.

Kardaş, Şaban. "Turkish-American Relations in the 2000s: Revisiting the Basic Parameters of Partnership?" Perceptions 16, no. 3 (2011): 25-52.

—_ "Türkiye ve Irak krizi: Kimlikle çıkar arasında AKP.” In Yavuz, AK parti, 359-89.

Kesgin, Baris, and Juliet Kaarbo. "When and How Parliaments Influence Foreign Policy: The Case of Turkey's Iraq Decision.” International Studies Perspectives 11, no. 1 (2010): 19-36.

Legro, Jeffrey W., and Andrew Moravcsik. "Is Anybody Still a Realist?" International Security 24, no. 2 (1999): 5-55.

Lobell, Steven E., Neal G. Jesse, and Kristen P. Williams. "Why Do Secondary States Choose to Support, Follow or Challenge?" International Politics 52, no. 2 (2015): 146-62.

Lobell, Steven E., Norrin Ripsman, and Jeffrey W. Taliaferro, ed. Neoclassical Realism, The State, and Foreign Policy. New York: Cambridge University Press, 2009.

Meibauer, Gustav, Linde Desmaele, Tudor Onea, Nicholas Kitchen, Michiel Foulon, Alexander Reichwein, and Jennifer Sterling-Folker. "Forum: Rethinking Neoclassical Realism at Theory's 
End.” International Studies Review (2020): 1-28. doi: /10.1093/isr/viaa018.

Milbrath, Lester W. "Interest Groups and Foreign Policy." In Domestic Sources of Foreign Policy, edited by James N. Rosenau, 231-51. New York: Free, 1967.

Monten, Janothan. "Primacy and Grand Strategic Beliefs in US Unilateralism." Global Governance 13, no. 1 (2007): 119-38.

Narizny, Kevin. "On Systemic Paradigms and Domestic Politics: A Critique of the Newest Realism." International Security 42, no. 4 (2017): 155-90.

Özcan, Gencer. "Türkiye dış politikasında algilamalar, karar alma ve oluşum süreci.” In Sömezoğlu, Türk dış politikasinın analizi, 829-95.

Özdamar, Özgür. "Dış politika karar alımı sürecinde lider merkezli yaklaşım: akılcı tercih kuramı ve Türkiye'nin Irak Savaşı'na katılmama kararı.” In Dış politika teorileri bağlamında Türk dış politikasınin analizi, edited by Ertan Efegil and Ridvan Kalayc1, 479-500. Ankara: Nobel, 2012.

Özlem, İpek. "Türk dış politikasında medyanın etkisi: 1 Mart 2003 tezkeresi." Unpublished Master thes., Yeni Yüzyıl University, 2018.

Öztop, Fatma Anıl. "Karar birimi kurami çerçevesinde Türk dış politikasının analizi: 1 Mart 2003 tezkeresi örneği." Uluslararası Politik Araştırmalar Dergisi 1, no. 2 (2015): 33-45.

Türk dış politikast yapım sürecinde karar birimlerinin etkileri. İstanbul: Gündoğan, 2018.

Ripsman, Norrin M. "Neoclassical Realism and Domestic Interest Groups." In Lobell, Ripsman, and Taliaferro, Neoclassical Realism, 170-94.

- Peace-Making by Democracies: The Effect of State Autonomy on the Post-World War Settlements. Pennsylvania: The Pennsylvania State University, 2002.

Ripsman, Norrin M., Jeffrey W. Taliaferro, and Steven E. Lobell. "Conclusion: The State of Neoclassical Realism.” In Lobell, Ripsman, and Taliaferro, Neoclassical Realism, 280-99.

Neoclassical Realist Theory of International Politics. New York: Oxford University, 2016.

Risse-Kappen, Thomas. "Public Opinion, Domestic Structure, and Foreign Policy in Liberal Democracies." World Politics 43, no. 4 (1991): 479-512.

Rose, Gideon. "Neoclassical Realism and Theories of Foreign Policy." World Politics 51, no. 1 (1998): 144-172.

Roth, Ariel Ilan. Leadership in International Relations: The Balance of Power and the Origins of World War II. New York: Palgrave Macmillan, 2010.

Sazak, Derya. "Erdoğan ikiz kuleler değişimi." Milliyet, February 2, 2002.

Schweller, Randall L. "Bandwagoning for Profit: Bringing the Revisionist State Back in." International Security 19, no. 1 (1994): 72-107.

. "Unanswered Threats: A Neoclassical Realist Theory of Underbalancing." International Security 29, no. 2 (2004): 159-201.

Sever, Ahmet. Abdullah Gül ile 12 yıl: Yaşadım, gördüm, yazdım. İstanbul: Doğan Kitap, 2015.

Sönmezoğlu, Faruk, ed. Türk dış politikasının analizi. 3rd ed. İstanbul: Der, 2004.

Taliaferro, Jeffrey W., Steven E. Lobell, and Norrin M. Ripsman. "Introduction: Neoclassical Realism, the State, and Foreign Policy.” In Lobell, Ripsman, and Taliaferro, Neoclassical Realism, 1-42.

Taydaş, Zeynep, and Özgür Özdamar. "A Divided Government, an Ideological Parliament, and an Insecure Leader: Turkey's Indecision about Joining the Iraq War.” Social Science Quarterly 94, no. 1 (2013): 217-41.

Trice, Robert H. "Foreign Policy Interest Groups, Mass Public Opinion and the Arab-Israeli Dispute." The Western Political Quarterly 31, no. 2 (1978): 238-52.

Tuncel, Gökhan. Sivil toplum ve devlet. Malatya: Bilsam, 2011. 
Tür, Özlem. "Türkiye'nin Irak ve Suriye İlişkileri." In XXI. Yüzyılda Türk dış politikasının analizi, edited by Faruk Sönmezoğlu, Nurcan Özgür Baklacığlu, and Özlem Terzi, 593-615. İstanbul: Der, 2012.

Türkeş, Mustafa. "NATO bağlamında ABD-Türkiye ilişkilerinde devamlılık ve değişim.” In Sömezoğlu, Türk dış politikasının analizi, 379-403.

Türkmen, Füsun. "Anti-Americanism as a Default Ideology of Opposition: Turkey as a Case Study." Turkish Studies 11, no. 3 (2010): 329-45.

—. "Turkish-American Relations: A Challenging Transition.” Turkish Studies 10, no. 1 (2009): 109-29.

Uslu, Nasuh. Çatlak ittifak: 1947'den günümüze Türk-Amerikan ilişsileri. Ankara: Nobel, 2016.

Uzgel, İlhan. "Dış politikada AKP: Stratejik konumdan stratejik modele.” In AKP kitabı: bir dönüşümün bilançosu, edited by Bülent Duru and İlhan Uzgel, 11-39. Ankara: Phoenix, 2010.

Vasquez, John A. "The Realist Paradigm and Degenerative versus Progressive Research Programs: An Appraisal of Neotraditional Research on Waltz's Balancing Proposition." The American Political Science Review 91, no. 4 (1997): 899-912.

Walt, Stephen M. "Alliances: Balancing and Bandwagoning." In International Politics: Enduring Concepts, and Contemporary Issues, Thirteenth Edition, edited by Robert J. Art and Robert Jervis, 153-61. New York: Pearson, 2016.

Wohlforth, William C. "Stability of a Unipolar World.” International Security 24, no. 1 (1999): 5-41.

Wohlforth, William C., and Stephen Brooks. "American Primacy in Perspective." Foreign Affairs 81, no. 4 (2002): 20-33.

World Out of Balance: International Relations and the Challenge of American Primacy. Princeton, N.J.: Princeton University, 2008.

Yalçın, Hasan B. "The Concept of "Middle Power" and the Recent Turkish Foreign Policy Activism." Afro Eurasian Studies 1, no.1 (2012): 195-213.

. "Making Sense of 1 March: A Proactive Strategy of Avoidance." Perceptions 18, no.1 (2013): $155-83$.

Yavuz, Hakan, ed. AK parti: toplumsal değişimin yeni aktörleri. İstanbul: Kitap, 2010.

Yeşiltaş, Murat. "Peşine takılma mı yumuşak dengeleme mi? Türkiye'nin Birinci ve İkinci Irak Savaşına yönelik ABD ile müttefiklik ilişkisinin karşılaştırmalı analizi.” In Mekân, kimlik, güç ve dış politika, edited by S. Gülden Ayman, 69-110. İstanbul: Yalın, 2012.

"Soft Balancing in Turkish Foreign Policy: The Case of the 2003 Iraq War." Perceptions 14, no. 1 (2009): 25-51.

Yetkin, Murat. “Irak’ta ABD’nin yanındayız.” Radikal, February 6, 2003.

—. Tezkere: Irak krizinin gerçek öyküsü. 2nd ed. İstanbul: Remzi, 2004.

Yılmaz, Samet. "Neoklasik realizm ve dış politika: 1 Mart tezkeresi örneği." Unpublished Master thes. Uludağ Üniversitesi, Bursa, Turkey, 2014. 